\title{
The Victory Day Celebrations in Israel in the Light of Articles in Russian-Language Israeli Web Portals
}

\begin{abstract}
The main aim of the article is to present a picture of contemporary celebrations of the Victory Day in Israel from the perspective of reports from Russian-language Israeli web portals. Although the tradition of celebrations dates back to 1950, the Victory Day did not become an official public holiday until 2017. Established on 9 May as the day of remembrance for the veterans of World War II, it resulted from the actions of the Russian-speaking population in Israel on two levels. The first was the political sphere and the activity of immigrant parties, especially Yisrael Beiteinu, in the work of the Knesset. The other was the social activity of local activists. However, both of these factors would not have been so effective if it were not for the reports of Russian-language Israeli media, in particular web portals. Although the arguments of the journalists associated with the portals were not always fully justified, their work contributed to the increased interest in the issue of veterans in Israel and Victory Day celebrations.
\end{abstract}

Keywords: Victory Day, Russian-language web portals in Israel, Victory Day Parade, media, Russian Jews.

Słowa kluczowe: Dzień Zwycięstwa, rosyjskojęzyczne portale internetowe w Izraelu, Parada Zwycięstwa, media, Żydzi rosyjscy.

\section{Introduction}

The influx of Russian-speaking immigrants from the lands of the former Soviet state caused irreversible changes in the social sphere of Israel. It is estimated that between 1970 and 2001, about 1,200,000 citizens of the USSR, and later also of Russia and other former republics of the Soviet Union, took advantage of the possibility resulting from the so-called right 
of repatriation (also known as aliyah). ${ }^{1}$ While initially the repatriations were dominated by people with clear Zionist beliefs, as early as the 1990s economic factors became the main motivation for immigration. Evidence for this include the falsification of birth certificates by some of the newcomers, on the basis of which they later referred to their supposed Jewish identity, as well as the arrival of mixed couples, the number of which among Soviet Jews was as high as 70 percent. ${ }^{2}$ A significant part of these immigrants had serious problems learning Hebrew as well as functioning in their new environment. The number of such newcomers in Israel in 2007 was estimated at about 350,000, although—as Larissa Remennick pointed out in her book-their actual numbers may be much higher. ${ }^{3}$

Very often, newcomers to Israel did not want to give up their previous identity developed in Soviet conditions. This was particularly difficult for the war veterans and their families, for whom issues of collective memory and difficult experiences were an extremely important part of their sense of community. This problem became apparent, inter alia, during the discussion of Victory Day celebrations and turning this date into a national event. Therefore, the decision made by the Knesset in 2017 to give this day the status of an official holiday in Israel and to choose 9 May as the date of its celebration had significant consequences because the inclusion of the Victory Day into official holidays meant a symbolic victory for the Soviet historical narrative in a country that had never belonged to the Eastern Bloc. It should be noted that the selected date of the celebrations was not 8 May adopted by western countries such as France or Great Britain, but 9 May which is the date used primarily in countries created after the fall of the USSR. ${ }^{4}$

The aim of this article is to trace the long-standing dispute over the need to commemorate the Victory Day in Israel by examining the perspective of the Russian-language web portals operating in the State of Israel.

${ }^{1}$ See Mark Tolts, "Demography of the Contemporary Russian-Speaking Jewish Diaspora," in Zvi Gitelman (ed.), The New Jewish Diaspora: Russian-Speaking Immigrants in the United States, Israel and Germany (New Brunswick-New Jersey, 2016), 23-40.

${ }^{2}$ Cf., e.g., Larissa Remennick, Russian Jews on Three Continents: Identity, Integration, and Conflict (New Brunswick-London, 2007); Majid Ibrahim Al-Haj, The Russians in Israel: A New Ethnic Group in a Tribal Society (London-New York, 2019).

${ }^{3}$ Remennick, Russian Jews, 61.

${ }^{4}$ The act of unconditional surrender of the Third Reich was signed on 8 May 1945 at 23:01 CET. In Moscow, according to the local time, it was already 01:01 of the following day. Apart from the countries that used to belong to the USSR, the date of 9 May is also celebrated as the Victory Day in the countries of the former Yugoslavia. 
Through a critical analysis of their contents, an attempt will be made to answer questions about the course of the celebrations, their organization, and the role played by Russian-speaking journalists during the debate over establishing 9 May as an official public holiday. The most important portals from the point of view of these considerations, including the website of Channel 9, the website edition of Vesti magazine, as well as MIGnews and NEWSru.co.il portals, have been selected for analysis based on the number of their followers in social media. ${ }^{5}$ They will be complemented by materials prepared by the editors of smaller portals, such as Israelinfo, the online editions of Haaretz, and The Jerusalem Post magazines, as well as reports presented by the official website of the Knesset.

\section{Beginnings of Victory Day celebrations in Israel}

The very tradition of celebrating the Victory Day in Israel dates back to the mid-twentieth century when, in 1950, near the Har Haruach Mountain, a forest was planted in memory of Red Army soldiers. This was made possible due to a collection taken up by a special committee for the commemoration of Red Army troops, which included Israeli communist activists such as Meir Vilner, Shmuel Mikunis, and Tawfik Toubi. The tree planting initiative was attended by residents of the kibbutz of Ma'ale HaHamisha located in the vicinity. According to the website of the present-day MAKI party, i.e. the Communist Party of Israel, the event also included the unveiling of a monument made of limestone on which the following words were engraved: "The citizens of Israel planted this forest in honor of the Red Army." ${ }^{\prime \prime}$ The forest was supposed to be a tribute to the Soviet soldiers fighting against the German army and to those who died in the wake of that war. But in reality, it also became an arena for public demonstrations associated with the far left and the MAKI party of that time. ${ }^{7}$ Anita Shapira, in her book Israel: A History, described it as an

${ }^{5}$ On Facebook alone, Channel 9 has 159,170 followers, Vesti - 110,060, MIGnews 45,418, and NEWSru.co.il - 17,595 (as of 11 August 2020).

${ }^{6}$ See "Be-Shabbat yetsuyan yom ha-nitsahon al germanyah ha-natsit ba-ya'ar ha-tsava ha-adom be-harey yerushalayim,” http://maki.org.il/בשבת-יצוין-יום-הניצחון-על-גרמניה-הנאצי/[retrieved: 2 Dec. 2019].

7 The first Israeli Communist Party was formed in 1948, but in the 1960s it began to weaken as a result of disputes between Jewish and Arab activists. The main focus of the conflict between the parties was the approach to the existence of the State of Israel, as well as the Israeli-Arab relations themselves. The final split occurred in 1965, when the proPalestinian RAKAH party separated and took over the majority of the far-left electorate. 
"anti-Zionist party which unreservedly supported the policy of the USSR." This opinion seems to be quite accurate, considering that it was its activists who dominated the Victory Day celebrations in the 1950s and 1960s.

However, the ceremonies were not only attended by far-left politicians, but also by Israeli representatives of the world of culture, who often sympathized with communism. These included the poet Alexander Penn. Despite leaving a country ruled by the Bolsheviks, he had strong ties with Marxism which, in his case, was reflected in his active membership of the MAKI party as well as in his poetry. ${ }^{9}$ The latter seems to be particularly significant. It is thanks to the Penn's poems that it is possible to learn about the dilemmas faced by immigrants from the Soviet state in Israel. These are perfectly illustrated, for example, by the poem entitled Moledet Hadasha [A New Homeland]. Importantly, this was the poet's first work in Hebrew, so, to some extent, it also has a symbolic dimension. The main theme of the work is the issue of Russian Jews adapting to the conditions prevailing in Palestine. The lyrical subject embodies the average newcomer from the Bolshevik state, who arrives in the land of his ancestors guided solely by his love for it. However, once he gets there, he has to face the brutal reality of the land, especially the harsh climate and the completely new environment. ${ }^{10}$ In this way, the poem presents some of the characteristic elements of Zionist rhetoric despite the communist views declared by the author, which are, after all, in complete opposition to Zionism.

Assuming that the work was based on the personal experience of its author, it may be assumed that other Jews who came to Palestine from the lands of the Soviet state, both in Penn's time and in later years, harbored similar feelings. Both the hot climate and the need to work hard, as well as other inconveniences not mentioned in the poem (such as the inability to speak the Hebrew language), made new settlers yearn for something

In 1989, after the final dissolution of the Israeli Communist Party, RAKAH returned to the name MAKI, which was supposed to emphasize its then dominant role in Israeli Communist circles. Cf. "New Communist List (Rakach)," in Parliamentary Groups, https://www. knesset.gov.il/faction/eng/FactionPage_eng.asp?PG =62 [retrieved: 2 Dec. 2019].

${ }^{8}$ Anita Shapira, Historia Izraela [Israel: A History], trans. Anna Dorota Kamińska (Warsaw, 2018), 235.

${ }^{9}$ So far, the figure of Penn has not been the subject of any extensive publication. Some information about him can be found in publications devoted to Russian-language Jewish literature. Cf., e.g., Yevrei v kul'ture russkogo zarubezh"ya. Sbornik statey, publikatsiy, memuarov i esse. Vypusk 1, 1919-1939 gg., ed. Mikhail Parkhomovskiy (Iyerusalim, 1992).

${ }_{10}$ Alexander Penn, Novaya rodina, trans. Mikhail Zenkevich, in Penn (Pen) Aleksandr, Izbrannye stikhi, http://e-libra.su/read/420376-izbrannye-stihi.html [retrieved: 7 Dec. 2019]. 
that minimized their sense of alienation, something that defined who they were and, at the same time, alluded to the culture and traditions of their "first homeland." When the poem was written in 1929, this factor was almost impossible to find, but after the end of World War II the void was filled by Victory Day celebrations primarily because organizations like the MAKI party could emphasize the role of Russian-speaking Jews serving in the Red Army in the fight against the German oppressors. Their advocacy is particularly important in modern times because, by adopting this rhetoric, new immigrants from the countries created after the fall of the USSR emphasized the role of their ancestors in the survival of the Jewish nation. This highlights another function of the Victory Day celebrations in Israel: the involvement in their cause of people who had no previous connections with the Soviet state or with the Red Army soldiers. The historical and political context of these celebrations made it possible to transfer-into the Israeli public sphere-elements of the Soviet historical narrative advantageous for immigrants, which also partially aligned with the memory of the Holocaust. This, in turn, would lead years later to significant changes in this field due to the participation of the Russianspeaking lobby in the Knesset. ${ }^{11}$

Both Penn's poems read during first Victory Day ceremonies and the impassioned speeches of politicians sympathizing with communism must have had a huge impact on the people gathering in the Red Army Forest. In fact, they became a kind of symbol of pro-Soviet sentiments in Israel. However, in the mid-1960s, the organizers were forced to stop organizing such ceremonies. This was primarily due to intra-party differences among members of the MAKI and the eventual separation of the RAKAH party in 1965 resulting from their sympathy with the Palestinians. The Communists-split into two separate groups-probably did not have enough strength to prepare similar undertakings on such a large scale. Neither was the political situation in the Middle East conducive to this. The outbreak of the Six-Day War in 1967 led to the USSR breaking off diplomatic relations with Israel; therefore, organizing any further public gatherings on the occasion of the Victory Day could have been interpreted as a form of solidarity with a hostile power. ${ }^{12}$

11 With regard to the activity of the Russian-speaking lobby itself in the contemporary Knesset, cf., e.g., Vladimir (Ze'ev) Khanin, “'Russkoye' lobbi v izrail'skoy politike 19962006 gg.," Vestnik Yevreyskogo universiteta (2008), 12:98-117.

${ }^{12}$ For the Israeli-Arab War itself, also known as the Six-Day War, and the relations between Israel and the Soviet state after 1967, see, e.g., Shapira, Historia Izraela, 359-411; 


\section{The celebrations today}

This tradition was revived in Israel only after the collapse of the Soviet state and re-establishment of diplomatic relations between Israel by the new Kremlin authorities. The Russian researcher Ilya Altman points to two main reasons for revival of the celebrations. First of all, it was connected with the phenomenon of mass aliyah in the 1990s and the arrival—in the State of Israel—of a large number of immigrants who were either veterans of the Red Army themselves and participated in the battles of World War II or who simply felt a personal connection with Victory Day ceremonies. ${ }^{13}$ Undoubtedly, these groups, influenced by a Soviet historical narrative, found space in Israel where they could redefine themselves. No wonder then that by celebrating the Victory Day these groups were able to express their own individual experiences of the war, which allowed them to align themselves with the existing memory of the Red Army troops fighting against Nazi invaders. The former Soviet Jews transformed from passive observers of discussions on history and began to shape its tone in the Israeli social sphere. This transformation is linked to the second reason cited by Altman for organizing the 9 May celebrations in Israel: the emergence and the intense activity of immigrant parties like Yisrael BaAliyah, existing between 1996 and 2003, and Yisrael Beiteinu, founded in 1999. ${ }^{14}$

The first Victory Day Parade in the State of Israel took place in 1995, but as time passed, there developed a need to formally regulate its organization. This was achieved by the Fourth Amendment to the Remembrance and Heroism Law, which was adopted on 30 July 2008. This provision gave responsibility for the preparation and course of the event to the Ministry of Immigrant Absorption (as of 2017, the Ministry of Aliyah

and Pauline Peretz, Let My People Go: The Transnational Politics of Soviet Jewish Emigration during the Cold War, trans. Ethan Rundell (New Brunswick-London, 2015), 135-190.

13 Ilya Altman, "Pochti polovina yevreyev Yevropy byla ubita natsistami v SSSR," [interview conducted by Artur Priymak, 31 July 2017], https://eadaily.com/ru/news/2017/07/31/ ilya-altman-pochti-polovina-evreev-evropy-byla-ubita-nacistami-v-sssr [retrieved: $30 \mathrm{Dec}$. 2019].

${ }^{14}$ Ibid. It should be noted that the phenomenon characteristic of many Israeli politicians who came from former Soviet lands was to start off their social careers with intense activities for immigrant groups, as reflected in membership of organizations, journalism, and research work. Cf. Khanin, “"Russkoye' lobbi,” 109-111. 
and Integration).${ }^{15}$ As a result, the celebrations gained greater national significance, even though supporters of elevating the Victory Day to the status of an official public holiday would have to wait nine more years for this to happen. Nevertheless, the adopted amendment proved to be exceptionally convenient for the Russian-speaking community, as the position of the head of the above-mentioned ministry has often been held by representatives of the "new immigrants." From 2008 to 2019, this function was performed by two such persons: Sofa Landver from Yisrael Beiteinu in 2009-2015 and 2016-2018, and Ze'ev Elkin representing Likud at the turn of 2015 and 2016. ${ }^{16}$

Even a cursory reading of Victory Day programs shows that contemporary celebrations commemorating the victory over the Third Reich are not limited to 9 May. For example, in 2011 they took on an exceptionally grand character, as the events associated with the holiday began on 6 May and lasted until 11 May. Such a long period of celebrating resulted from the organizers wanting to take advantage of Independence Day falling on that time in Israel. ${ }^{17}$ Regardless of the circumstances, the most important element of the celebrations was a ceremony in Jerusalem. The entities responsible for organizing the celebrations had been, after all, municipal authorities working with representatives of the Ministry of Absorption. An important role was also played by veterans brought together by the Israeli Association of World War II Veterans. ${ }^{18}$ In 2010, the celebrations began at 11:00 a.m. when columns of veterans accompanied by families, young people, local residents, and journalists set off from the Hamashbir department store. The participants marched along Hillel Street toward Rome Square, where official part with politicians and foreign diplomats took place. Among the attendees were the leader of the opposition in

15 See "Hok yom ha-zikaron la-shoah ve-la-gevurah (tikun mispar 4), 5768-2018, 30 July 2008," https://fs.knesset.gov.il/17/law/17_lsr_300867.pdf [retrieved: 29 Dec. 2019].

${ }_{16}$ The complete list of Ministers of Immigrant Absorption, as well as of Aliyah and Integration, is available on the Knesset's website. See "All Ministers in the Ministry of Immigrant Absorption," in All Governments in Israel, https:/www.knesset.gov.il/govt/eng/ GovtByMinistry_eng.asp?ministry=20 [retrieved: 29 Dec. 2019].

17 The Israeli Independence Day is a movable holiday due to the fact that it is celebrated according to the Jewish calendar. According to this calendar, Israel's independence was proclaimed on 5 Iyar 5708. In 2011, this day began in the evening of 9 May and lasted until the evening of the following day.

${ }^{18}$ Their involvement is mentioned by such web portals as NEWSru.co.il. Vide, e.g., "Den' Pobedy v Iyerusalime: 'Glavnaya nagrada - my vyzhili'," http://newsru.co.il/ israel/09may2010/parad476.html [retrieved: 2 Jan. 2020]. 
the Knesset, Tzipi Livni, as well as the then Minister of Absorption, Sofa Landver.

In their speeches to the veterans, politicians very often tried to emphasize the contribution of the Red Army soldiers to the creation of the State of Israel, and some even tried to stress their personal relationship with 9 May and the struggle for the survival of the Jewish nation. These motifs were present, for example, in the statements of Livni, who said the following during the celebration in 2016:

I am a daughter of Irgun fighters, a mother of officers of the Israel Defense Forces-today I want to thank the veterans and say that our relationship is deep, and that my children, who carry out combat missions during their service, continue the traditions of the veterans who won this war. ${ }^{19}$

These words were later quoted by many Russian-language media outlets in Israel, including Channel 9, which suggests that recognition of the Red Army soldiers' merits by Israeli politicians was extremely important at the time.

Thanks to the support of the Israeli government, Victory Day celebrations gradually started to be included in the schedules of many Israeli citizens. Consequently, as years passed, more cities began including this holiday in their calendars. An excellent example of this phenomenon is Haifa, the largest city in northern Israel. The concept of organizing a Victory Parade there was born among the employees of the Cultural Department of the local Municipal Office of Absorption. The project was also supported by the then mayor of the city, Yona Yahav. ${ }^{20}$ The first veterans' parade in Haifa took place in 2004, and its route was limited to Nordau Street. Only a year later, the route of the march passed along the much more representative Herzl Street, which since that first year has to be closed every year to let the parade's participants use it. ${ }^{21}$ That was the beginning of organizational changes that gradually increased the importance of the event. As reported by the ISRAland portal in 2007, with each subsequent parade, new elements of the celebrations began to appear, almost immediately becoming a part of the new local tradition. These included the giving of flowers to the marching veterans by

\footnotetext{
19 "Parad Pobedy v Iyerusalime," http://archive.9tv.co.il/news/2016/05/08/225401.html [retrieved: 2 Jan. 2020].

20 "Parad Pobedy v Khayfe," http://www.isra.com/news/83126 [retrieved: 1 Jan. 2020].

${ }^{21}$ Due to the Victory Parade, it is closed every year for 40 minutes, allowing participants to freely complete the planned route.
} 
local residents, meetings with politicians and concerts. One may get a full picture of Victory Day celebrations in Haifa by analyzing the program of the event, which is attached to the article from the ISRAland portal mentioned above.

A review of the program indicates that the whole 2007 celebration in the city fell on 9 May. It started with a gathering of the participants at 9:30 a.m. next to the Beit Hakranot ${ }^{22}$ office building on Herzl and Balfour Street. It is noteworthy that not only Red Army soldiers were invited to participate in the march, but also former prisoners of camps and inhabitants of ghettos, which, in a way, had a symbolic dimension as it united two historical narratives that function in Israel. ${ }^{23}$ After the giving of flowers by activists from the "We in Our Home" Society, ${ }^{24}$ members of the city's Council of Veterans began to position the participants in columns. Precisely at 10:00 a.m., the parade's participants marched out to the accompaniment of a brass band. On their way, they were greeted by the local youth, students, and residents. The march ended at the amphitheater on Nordau Street, where, after a short rest, the artistic part began. Over time, the Victory Parades in Haifa became some of the largest in the country. ${ }^{25}$ This was exhilarating especially to the veterans involved in organizing them. One of them, Yevgeny Levengard, said ten years later in an interview with a journalist from MIGnews.com: "When we organized the Parade, people said that no one would come. But 400 people came. And this year [2017], the Parade that we organized on 5 May was attended by 15,000 people."26 This increase in the number of parade participants over the years, which happened not only in Haifa but also in other cities such as Ashkelon and Bat Yam, can be explained by the steadily increasing popularity of the event due to lively public debate about it.

But this process did not always take place in a calm atmosphere. In 2016, Channel 9 reported on the events happening in the Red Army Forest, which, after more than half a century, became a place of 9 May celebrations again. There was a conflict between the official delegation of the Russian Federation with veterans and members of the communist

${ }^{22}$ Literally, "House of the Funds." It is a grand office building in Haifa, erected in 1939.

${ }^{23}$ Ibid.

${ }^{24}$ An Israeli social organization based in Haifa.

${ }^{25}$ Cf., e.g., "V pyatnitsu v Khayfe proydet bol'shoy parad Pobedy," in Novosti Izrailya, https://news.israelinfo.co.il/tribune/71944 [retrieved: 1 Jan. 2020].

26 "Kakhlon: 'Blagodarya veteranam my nakhodimsya zdes' segodnya'," http://mignews.com/news/politic/world/090517_140358_21970.html [retrieved: 2 Jan. 2020]. 
Association of Friendship among Nations composed mainly of activists of Arab origin. According to journalists' reports, the activists disturbed the course of the ceremony by shouting and singing The Internationale. ${ }^{27}$

Taking a closer look at preparations for the celebrations, one is able to identify at least a few organizations involved in planning them. On the one hand, the involvement of the Ministry of Immigrant Absorption as provided for in the provisions of the law reflected the organizational power of the central government. On the other hand, local politicians, as the case of Haifa has shown, are often the initiators of Victory Day events. One should not forget the role played by veterans in the preparation of the celebrations, represented mostly by organizations such as the Israeli Association of World War II Veterans or the local Councils of Veterans. Moreover, one may add to this list groups directly tied to Russia. An excellent example is the 2011 celebration, during which a concert for World War II veterans was organized in the city of Petah Tikva. Although its main organizers were local motorcyclists, it was held in close cooperation with the Russian Cultural Center in Tel Aviv. ${ }^{28}$ The significance of this fact is that it shows how strong the Russian influence has been on recognizing of the Victory Day within Israeli society.

At this point, it should be clear that this Russian impact has been and continues to be noticeable in Israeli social and political spheres. In the latter, the activities of the Yisrael Beiteinu party and its leader, Avigdor Lieberman, should be highlighted. This political grouping, which is largely made up of representatives of the Israeli Russian-speaking community, has repeatedly raised at the Knesset issues concerning the recognition and social security of World War II veterans. This is not surprising, considering the fact that the party leader himself is the son of a former Red Army soldier ${ }^{29}$ Interestingly, Lieberman himself was previously associated with Likud and Benjamin Netanyahu. In the biography of the Israeli Prime Minister Anshel Pfeffer one may find information that Lieberman "opened Bibi's eyes to the electoral potential of the Israeli

${ }^{27}$ See "Araby v lesu pod Ierusalimom pomeshali posol'stvu RF otmetit' Den' Pobedy," http://archive.9tv.co.il/news/2016/05/09/225458.html [retrieved: 1 Jan. 2020].

${ }^{28}$ Cf. "Den' Pobedy v Izraile. Parad veteranov i kontsert baykerov," http://newsru.co.il/ photo/09may2011/pobeda_103.html [retrieved: 2 Jan. 2020].

${ }^{29}$ Cf. "Avigdor Liberman: strategiya uspekha," https://ndi.org.il/liberman-bio/ [retrieved: 11 Aug. 2020]. 
Russian-speaking community." ${ }^{30}$ Therefore, it may be assumed that for Netanyahu himself the issue of celebrating the Victory Day was also important. On the one hand, it was an opportunity to expand the electorate of Likud in subsequent elections, and on the other hand, it was also a chance to improve relations with Russia, which was extremely important in the face of the ongoing civil war in Syria.

Despite the apparent participation of representatives of the State of Israel in the organization of Victory Day celebrations, some Russianlanguage media occasionally reported an alleged lack of interest in the lives of veterans on the part of Israeli journalists and politicians. Such information was provided (inter alia, after the 2010 celebration) by the NEWSru.co.il portal, whose editors published an article stating that "the Israeli press nearly 'forgot' about the Victory Day." 31 The very construction of this headline indicates a kind of subjectivity in its evaluation. The author states that leading Israeli newspapers ignored Victory Parades organized in the country. The celebrations in Moscow supposedly aroused more interest among journalists, although, in the opinion of the editor, even they were described only in a perfunctory way. ${ }^{32}$ The report in the liberal daily Haaretz was singled out since it provided brief information about the Moscow celebrations and referred the readers to the Russian Novaya Gazeta, but this criticism that coverage was lacking is only thinly supported, given that the columnists of Haaretz wrote about the problems that World War II veterans were facing in contemporary Israel. ${ }^{33}$ Moreover, the 2010 ceremonies were quite extensively covered by another Israeli mainstream newspaper-The Jerusalem Post-which quoted, for example, the words of Prime Minister Benjamin Netanyahu who, in his speech, discussed the losses among the Soviet Jews fighting in the ranks of the Red Army. ${ }^{34}$ Therefore, publications up until 2017 should be treated as politically motivated and aimed at officially attributing an important role to the Red Army in the Israeli historical narrative. In turn, greater interest by the Israeli media in the 9 May celebration

${ }^{30}$ Anshel Pfeffer, Bibi. Burzliwe życie i czasy Beniamina Netanjahu, trans. Anna Halbersztat (Katowice, 2020), 186-187.

31 “Izrail'skaya pressa pochti 'zabyla' pro Den' Pobedy," http://newsru.co.il/israel/ 09may2010/poveda_102.html [retrieved: 2 Jan. 2020].

${ }^{32}$ Ibid.

${ }^{33}$ Cf., e.g., "Jewish Veterans of Soviet Red Army Suffering in Solitude," https://www. haaretz.com/jewish/jews-of-red-army-suffer-in-solitude-1.5241033 [retrieved: 3 Jan. 2020].

34 “Gov't grants J'lem special status," https://www.jpost.com/Israel/Govt-grants-Jlemspecial-status [retrieved: 3 Jan. 2020]. 
in Moscow might be explained by the absence of important Western leaders from it, such as the then US President Barack Obama or British Prime Minister Gordon Brown. Their absence had much greater political consequences than the local parades of veterans, which must have been clear to Israeli journalists.

\section{The Victory Day as an official public holiday}

The issue of recognizing the Victory Day as an official public holiday in Israel could only be resolved by the Knesset's adoption of an appropriate law. Both politicians and social activists from the Israeli Russian-speaking community took actions that led to its creation. However, some steps in were also taken outside the State of Israel. In 2014, the president of the World Congress of Mountain Jews and the vice-president of the Russian Jewish Congress-German Zakharyayev-submitted an application for inclusion of the 9 May celebrations in the official Jewish calendar. This finally happened in 2015, thanks to the support of, among others, the Chief Rabbis of Russia and Israel. ${ }^{35}$ Undoubtedly, this fact deserves special attention because the religious Jewish community adapted-for the purposes of its traditions - an event that for years had been a symbol of a system that excludes all manifestations of piety from its public space, especially piety connected with Judaism. It even got its own Hebrew name Yom Shichrur ve-Atsala, which can be translated as "Day of Salvation and Liberation."

Zakharyayev made other efforts to secure a place for Red Army soldiers in the historical memory of the citizens of Israel. The fact that the celebrations were given a religious character legitimized the actions of their supporters in the Jewish state, depriving the Victory Day of a strictly Soviet character. Nevertheless, taking more decisive steps toward making the Victory Day more mainstream was still necessary, and those steps aroused interest not only in the Russian-language Israeli portals, but also in the "mainstream" ones. The Jerusalem Post reported that thanks to the financial support of Zakharyayev, a special organization, called the Victory Day Headquarters, was established. The sponsor himself said that the organization's existence was justified by "the need to call for action, so that

${ }^{35}$ See "Pobeda, spaseniye, osvobozhdeniye: chto otmechayut yevrei Rossii 9 maya," https://www.vesty.co.il/articles/0,7340,L-5256650,00.html [retrieved: 3 Jan. 2020]; Altman, "Pochti polovina yevreyev Yevropy." 
this legacy [of Soviet Jewish soldiers] is not forgotten." ${ }^{36}$ In turn, one of the activists of both the Headquarters and the Russian Jewish CongressBenny Briskin—emphasized in his talks with journalists that "the Jewish struggle was an integral part of the Jews' salvation." ${ }^{37}$ The examples that he gave included the fate of Soviet Army officer Anatoly Shapiro-the person who opened the gates of the Auschwitz concentration camp ${ }^{38}$ to let the prisoners out. The organization commissioned a special survey which was conducted in 2015 by the Dialog Institute under the supervision of Camil Fuchs of Tel Aviv University. It revealed that 48 percent of those surveyed were in favor of recognizing the Victory Day as an official public holiday in Israel..$^{39}$ Even though this percentage did not make up a majority of respondents, it constituted a sizeable electorate that far exceeded the number of voters from the former USSR, which never went beyond a dozen or so percent of those eligible to vote in the Knesset elections.

And so, the issue of establishing the Victory Day as a public holiday, much like the work on the law concerning the status of veterans years earlier, was an opportunity for the ruling coalition led by Netanyahu (but also for smaller parties, such as Yisrael Beiteinu, or for Avigdor Lieberman himself) to expand its traditional electorate. Due to the subject matter and its close connections to immigrants from the former Soviet state, the people most interested in the 9 May celebration turned out to be politicians of Lieberman's party. Interestingly, however, one of its members, Oded Forer-who, although representing a party originating from a Russianspeaking community, did not belong to this group—became the leading figure in the creation of the law that would give the Victory Day an official state designation. ${ }^{40}$ When preparing the provisions of the document, Forer

${ }^{36}$ Sam Sokol, "Almost half of Israelis support making the Victory Day a national holiday,” https://www.jpost.com/Israel-News/Almost-half-of-Israelis-support-making-VictoryDay-a-national-holiday-402057 [retrieved: 3 Jan. 2020].

${ }^{37}$ Cf., e.g., "Den' Pobedy v Izraile vpervyye budet otmechat'sya i po yevreyskomu kalendaryu," http://newsru.co.il/israel/04may2015/day.html [retrieved: 3 Jan. 2020].

${ }^{38}$ Ibid. Lt.-Col. Anatoly Shapiro (1913-2005) served as commander of the 1085th Rifle Regiment in January 1945, and participated in the battles for the city of Oświęcim. Earlier, he had participated, among others, in the Battle of Kursk. From 1992, he lived as an expatriate in the United States. See "Anatoly Shapiro (1913-2005)," https://www.jewishvirtuallibrary.org/anatoly-shapiro [retrieved: 5 Jan. 2020].

${ }^{39}$ Sokol, "Almost half of Israelis."

${ }^{40}$ As Forer explained in an interview for the Russian-language Vesti magazine, his ancestors came from the area of Brest, which now lies in the territory of Belarus. But, thanks to working at the Ministry of Immigrant Absorption, he learned more about the problems and worldview of repatriates from the former USSR. Cf. Oded Forer, "Eto ne moy secret," 
was also supported by other right-wing politicians, in particular Robert Ilatov and Yulia Malinovsky. ${ }^{41}$ As Forer explained, the main goal of his team was to "repay the moral debt to the veterans for saving humanity from Nazism." 42 The bill (i.e. the draft law) was presented during the Knesset's session in March 2017, after which the decision was made to submit it for further revision. The draft, despite being unanimously passed in the preliminary reading, aroused some criticism, inter alia, from orthodox parties, including Deputy Minister of Education Meir Porush, who believed, for example, that instead of 9 May, the law should provide for the date of the end of the war according to the Jewish calendar. ${ }^{43}$

The final vote was taken during the 25 July 2017 session. The Law on the Day of Victory over Nazi Germany was once again unanimously voted through with the support of 28 members of the Knesset. ${ }^{44}$ Article 1 states that the law's main purpose was to designate the commemoration date of the Allies' victory over Nazi Germany and to honor the heroism of the Allies, while emphasizing the contribution of Jews fighting in Allied armies. ${ }^{45}$ This date was to be the annual Day of Victory over Nazi Germany falling on 9 May, although the document allowed for the possibility of organizing the celebrations on other May days. Importantly, the date was statutorily a time off from work and school. Further, the law somewhat regulated the form of the celebrations, e.g., by imposing an obligation on schools to prepare classes on topics related to the new public holiday and organizing other educational events and meetings with the participation of the international community. ${ }^{46}$ The person watching over the course of the ceremonies was to be the Minister of Aliyah and Integration, who was also tasked with the distribution of public funds among local governments preparing the celebrations. At the same time, the minister was to

[interview conducted by the editorial team of Vesti, 10 Aug. 2017], https://www.vesty.co.il/ articles/0,7340,L-5001445,00.html [retrieved: 5 Jan. 2020].

41 "Zakonoproyekt o chestvovanii Dnya Pobedy 9 maya utverzhden v predvaritel'nom chtenii," in Novosti Knesseta, https://knesset.gov.il/spokesman/ru/template_ru.asp?PRId= 2078 [retrieved: 6 Jan. 2020].

${ }^{42}$ See "V NDI namereny zakrepit' prazdnik 9 maya zakonodatel'no," http://archive.9tv. co.il/news/2017/03/22/240519.html [retrieved: 6 Jan. 2020].

43 "Zakonoproyekt o chestvovanii Dnya Pobedy."

44 "Knesset utverdil v pervom chtenii zakon o 9 maya," http://www.newsru.co.il/ israel/26jul2017/zakon_704.html [retrieved: 6 Jan. 2020].

45 "Hok yom ha-nitsahon al germanyah ha-natsit, 5777-2017, 25 July 2017," https:// main.knesset.gov.il/Activity/Legislation/Laws/Pages/LawBill.aspx?t=LawReshumot\&lawit emid=2015238 [retrieved: 6 Jan. 2020].

${ }^{46}$ Ibid. 
continue to organize the Victory Parade in Jerusalem and was also given prerogatives to effectively enforce the provisions of the law.

It is therefore not surprising that the subsequent Victory Day celebrations, held in 2018, were exceptional. For the first time, they were organized in Israel as an official public holiday. According to the Russian-language website of the Knesset, during the Victory Parade in Jerusalem on 8 May, about 400 veterans together with hundreds of young people from various youth organizations marched through the streets of the city. ${ }^{47}$ High representatives of the State of Israel spoke at the ceremony, most notably Yuli Edelstein, Chairman of the Knesset. His speech was clearly political in nature, as he stated that the example of World War II veterans was proof that there were threats to the State of Israel which "could not be silenced with words." ${ }^{48}$ Other participants of the event included Avigdor Lieberman as Minister of Defense and Sofa Landver as Minister of Aliyah and Integration. As can easily be noticed, despite giving the Victory Day an official designation, celebrations continued to attract the interest of, above all, politicians and activists directly connected to former Soviet Jews.

\section{Conclusion}

The formal adoption of the Victory Day in Israel was an exceptionally complex process. Although initially directly connected with Communist circles, in modern times it has taken on new dimensions owing to both political and social factors. Participants did not simply commemorate victory over Germany, but more broadly recognized the sufferings of Jews as a result of World War II. This is perfectly illustrated by the statement of Tzipi Livni, who thanked veterans for their contribution to the survival of the Jewish people. What is more, the efforts of Russian-speaking Jewish circles led to this holiday assuming a religious character. As a result, it may be concluded that the only remnants of the Communist origin of the Victory Day are the date of 9 May (although the ceremonies themselves may take place on other days as well) and the parades that had been traditionally organized.

Throughout this process, Russian-speaking journalists and their editorial teams played an extremely important role. Initially, it was mostly

\footnotetext{
47 “Knesset shiroko otmetil 73-y Den’ Pobedy," https://knesset.gov.il/spokesman/ru/ template_ru.asp?PRId=2327 [retrieved: 6 Jan. 2020].

${ }_{48}$ By saying these words, Edelstein meant, in particular, the threat from Iran. See ibid.
} 
limited to presenting accounts of the celebrations and the accompanying Victory Parades, which contributed to their growing popularity among former Soviet Jews and their families. However, during the debate on the recognition of 9 May as an official public holiday, journalists, along with politicians from immigrant and veteran circles, became important in advancing the Victory Day cause. Taking advantage of the growing popularity of web portals, they skilfully presented the sacrifice of Jewish soldiers of the Red Army as a factor that determined the survival of the nation. Moreover, Russian-speaking columnists were also able to enter into polemics with the largest editorial offices of Israeli newspapers. The example of NEWSru.co.il's 2010 reports showed that, although the arguments of these journalists were not always justified, they certainly contributed to the increased interest in the issue of veterans in Israel. All these factors, in turn, laid the foundation for finally giving these celebrations a public designation in 2017.

\section{Bibliography}

\section{Primary sources}

9 Kanal, https://www.9tv.co.il/ [retrieved: 6 Jan. 2020].

Haaretz (online), https://www.haaretz.com/ [retrieved: 3 Jan. 2020].

"Hok yom ha-nitsahon al germanyah ha-natsit, 5777-2017, 25 July 2017," https:// main.knesset.gov.il/Activity/Legislation/Laws/Pages/LawBill.aspx?t=LawRe shumot\&lawitemid $=2015238$ [retrieved: 6 Jan. 2020].

"Hok yom ha-zikaron la-shoah ve-la-gevurah (tikun mispar 4), 5768-2018, 30 July 2008," https://fs.knesset.gov.il/17/law/17_lsr_300867.pdf [retrieved: 29 Dec. 2019].

Izrail' na ladoni - Israelinfo, https://israelinfo.co.il/ [retrieved: 1 Jan. 2020].

The Jerusalem Post (online), https://www.jpost.com/ [retrieved: 3 Jan. 2020].

MIGnews: Novosti Izrailya i Blizhnego Vostoka, https://mignews.com/ [retrieved: 1 Jan. 2020].

NEWSru.co.il: Novosti Izrailya i mira, http://newsru.co.il/ [retrieved: 6 Jan. 2020]. The official website of the Knesset, https://main.knesset.gov.il/Pages/default.aspx [retrieved: 6 Jan. 2019].

Penn, Alexander, Novaya rodina, trans. Mikhail Zenkevich, in Penn (Pen) Aleksandr, Izbrannye stikhi, http://e-libra.su/read/420376-izbrannye-stihi.html [retrieved: 7 Dec. 2019].

Portal ISRAland - izrail'skiye novosti, http://www.isra.com/ [retrieved: 1 Jan. 2020].

Vesty.co.il: Vesti Izrail', https://www.vesty.co.il/home/0,7340,L-50,00.html [retrieved: 5 Jan. 2020]. 


\section{Secondary sources}

Al-Haj, Majid Ibrahim, The Russians in Israel: A New Ethnic Group in a Tribal Society (London-New York, 2019).

Altman, Ilya, "Pochti polovina yevreyev Yevropy byla ubita natsistami v SSSR," [interview conducted by Artur Priymak, 31 July 2017], https://eadaily.com/ ru/news/2017/07/31/ilya-altman-pochti-polovina-evreev-evropy-byla-ubitanacistami-v-sssr [retrieved: 30 Dec. 2019].

"Anatoly Shapiro (1913-2005)," https://www.jewishvirtuallibrary.org/anatolyshapiro [retrieved: 5 Jan. 2020].

"Be-Shabbat yetsuyan yom ha-nitsahon al germanyah ha-natsit ba-ya'ar ha-tsava ha-adom be-harey yerushalayim," http://maki.org.il/בשבת-יצוין-יום-הניצחון-על-גרמניה-הנאצי/[retrieved: 2 Dec. 2019]. Khanin, Vladimir (Ze'ev), "'Russkoye' lobbi v izrail'skoy politike 1996-2006 gg.," Vestnik Yevreyskogo universiteta (2008), no. 12.

Parkhomovskiy, Mikhail (ed.), Yevrei v kul'ture russkogo zarubezh"ya. Sbornik statey, publikatsiy, memuarov i esse. Vypusk 1, 1919-1939 gg. (Iyerusalim, 1992).

Peretz, Pauline, Let My People Go: The Transnational Politics of Soviet Jewish Emigration during the Cold War, trans. Ethan Rundell (New Brunswick-London, 2015).

Pfeffer, Anshel, Bibi. Burzliwe życie i czasy Beniamina Netanjahu, trans. Anna Halbersztat (Katowice, 2020).

Remennick, Larissa, Russian Jews on Three Continents: Identity, Integration, and Conflict (New Brunswick-London, 2007).

Shapira, Anita, Historia Izraela, trans. Anna Dorota Kamińska (Warsaw, 2018). Tolts, Mark, "Demography of the Contemporary Russian-Speaking Jewish Diaspora," in Zvi Gitelman (ed.), The New Jewish Diaspora: Russian-Speaking Immigrants in the United States, Israel and Germany (New Brunswick-New Jersey, 2016).

Krystian Propola University of Rzeszów k.propola@gmail.com 